\title{
120 Years on: voices on child abuse
}

Roy Meadow

A cry for help

"It can't have been very bad because they only gave me a year's probation." She sat back, squat and seeming self satisfied. She showed me how she had held him down with her left arm as she put her right hand over his face and mouth. Yes he did struggle, but the left arm pinned him down. Her other child had died suddenly and unexpectedly at the age of 9 months. If she had been a man she would have been in Broadmoor or Rampton. If she had been a man who had inappropriately fondled his daughter a prison sentence would have been likely. But the judge had "no doubt that she loved her son and indeed loved all children." He was sure there was no malevolence on her part and that she was in need of help not punishment. It was, as the social worker had testified, a cry for help.

The lift was broken. The stairs of the block were littered with garbage and the walls covered with graffiti. The main room of her flat had four pieces of furniture: a television set, a small table, a chair, and an empty cocktail cabinet. There was a pile of dirty laundry in the corner. The two children, to whom, she had said on the telephone, she had done the most awful things, were asleep in the next room. She talked about herself, her feelings, and her needs and went on, and on, and on. The children were rarely mentioned, nor could the conversation be steered to what she had done to them, not because she was unwilling to admit it but because it seemed of less importance to her than her own problems. He couldn't work out what the smell was: it wasn't from the cocktail cabinet nor from the pile of dirty laundry. "It's nothing," she said, "its not coming from there." But it was coming from therefrom the room where the children were sleeping. He said he was going in. There was a big canister, and the smell came from paraffin that soaked the two beds. The children slept on oblivious.

"If you hadn't come I was going to finish us all off," she said. Was it just a cry for help?

\section{Case conferences}

Although case conferences rarely started on time there was a buzz of chatter and laughter from the 15 people already assembled when he arrived. Most seemed to know each other well, and he felt a bit out of place. Absolutely anyone who knew the child and the family was there, plus some who definitely did not. The health visitor was there to give her impression of the family and, though the health visitor was a confident mature woman, her supervisor accompanied her to give support. The man and woman in the smart suits and the clean shoes were probably police constables. The school nurse was there, and the child's teacher, and also the head teacher (perhaps to support the other two). The man in the sports jacket was the probation officer for the guilty father. The school medical officer had cancelled her afternoon clinic to be there and so had the psychiatric senior registrar. The paediatrician was worried about whether he had been right to cancel appointments with two new patients and 12 follow up patients in order to attend this meeting. He envied the general practitioner, who had sent apologies for non-attendance, and wondered who had the correct sense of priorities. Sometimes something new emerged, but usually each person related what was already known or available as written information. Nearly everyone at that meeting was a well paid professional person with a large list of clients. Most had cancelled their appointments to attend the case conference and some attended several such conferences a month.

Case conferences had been created in the 1970 s to encourage a multidisciplinary approach to child abuse and a collective decision about the child's future safety. Some doctors did not like them, ostensibly because of the time involved but also, perhaps, because they doubted that committees were the best forum for solving complex and tragic problems.

The usual outcome was an agreement to put the child, with or without the other siblings, on the Child Protection Register. In all 40000 children in England and Wales were currently on such registers and were regularly reviewed by the social services. If any future doctor or social worker encountering the child was worried about the welfare of the child or the possibility of abuse they could telephone and find out whether the child was on the register. Sometimes the conference decided that the child was not safe in that home, and the unpleasant task of going round to the family to tell them and take the child away would be delegated at the meeting to two of those present-usually social workers.

Afterwards, as he walked back to his car, the paediatrician reflected that he was glad that he did not have that task.

\section{Wards of court}

"It depends on the standard error of the method and whether there has been inhibition of liver enzymes by other drugs." The chairman of the Bench that day, a head teacher with a degree in English, was not enjoying the evidence of the clinical pharmacologist, nor were his fellow magistrates-a girl guide commissioner and a local storekeeper. They sat on a slightly raised platform at one end of the village hall. In the middle was a large rectangular table across which the two parties sat facing each other and within touching distance. No one stood to give evidence, not even the barrister, and the experts sat facing the mother telling her how she had regularly administered dangerous drugs to the child.

The medical evidence was complex, and the case went on for several days. He wondered why it had not been heard in the family division of the High Court, where more difficult cases were heard by experienced judges who were surprised by nothing. But most cases arrived in the High Court as a result of wardship proceedings, which were costly for the local authority and entailed long delay because of the queue for court time.

Wardship had been introduced in another age to prevent young heiresses from being taken out of the country by impetuous rakers. In the past the Lord Chancellor had had an annual garden party to which he had invited all wards of court, and it was a beautiful occasion. In more recent years the Lord Chancellor had not been known to invite children who were wards 
of court to any party. They are changing the law to limit the use of wardship for child abuse cases; perhaps the garden parties will resume.

The father had put on a shirt and tie and his suit for the occasion, but he still looked a very ordinary fellow. He had worked in the Army Catering Corps before taking up work as a labourer. He'd married late. He said that he was very fond of children, but though he had had two children by a previous relationship, he had not seen either child for over five years. He knew that his wife had been under pressure, but everything was different now: they even talked to each other about problems. He said that he loved children and that he'd do anything, absolutely anything, to get the child back: "I'll even give up my membership" (of an anglers' society) and "sell my new rod" (which cost £76). The previous week another husband had said that he would give up aeroplane spotting "forever"; and the week before the one who was a night watchman had promised never to go to away matches again. They rarely give up their wives - at the time. Even those who have been poisoned by their wives still stick by them - at the time. The fathers say "It was a cry for help, that's why she did it." The mothers say they'll kill themselves if they don't get their child back; and some of them do perform a ritual cutting of the wrist or swallowing of tablets. But it is some of the fathers, a year or two later, who drown, hang, or gas themselves. They do not seem to go in too much for cries for help.

\section{Easy to identify?}

The stations were the names of lower division football teams of his childhood. It was grey and the drizzle slanted on to the slag heaps and derelict factories. It was a depressing place with old, ugly, small buildings. There was nothing beautiful and nothing fine to see. He'd been told that the social services offices were within walking distance of the station - first turning on the right, after the garage. He took a long time finding them even though they were just where they had said. The problem was that the first turning on the right led to the only magnificent building in the suburb, a massive mirrored glass tower with a colonnade, ornamental steps, and a flamboyant fountain. What a strange place to have a building

\section{Dormitory of Hospital (1889) \\ Vincent van Gogh (1853-90; Dutch)}

December 1888 was a turning point in van Gogh's life: after a violent quarrel with Gauguin he mutilated his ear. Months of mental instability followed, and this picture was painted during his time in the asylum at Saint-Rémy. It is intensely lonely, with no communication among the group of patients seated round the stove, each lost in his own thoughts. The desultory shambling of the remaining three patients emphasises the hopelessness of the situation, contrasting with the purposeful attitudes of the nuns. Van Gogh has exaggerated the length of the ward by distorting the perspective and by using bold vertical brushstrokes so that the door, surmounted by a cricifix, becomes an unattainable goal. This is one of a remarkable series of works that van Gogh painted at SaintRémy-the energy of his brushwork contrasts poignantly with the apathy of the patients portrayed.

\section{CLASSIC OF THE DECADE}

1886-8: Sir William Gowers' Manual of Diseases of the Nervous System (two volumes). London: J and A Churchill.

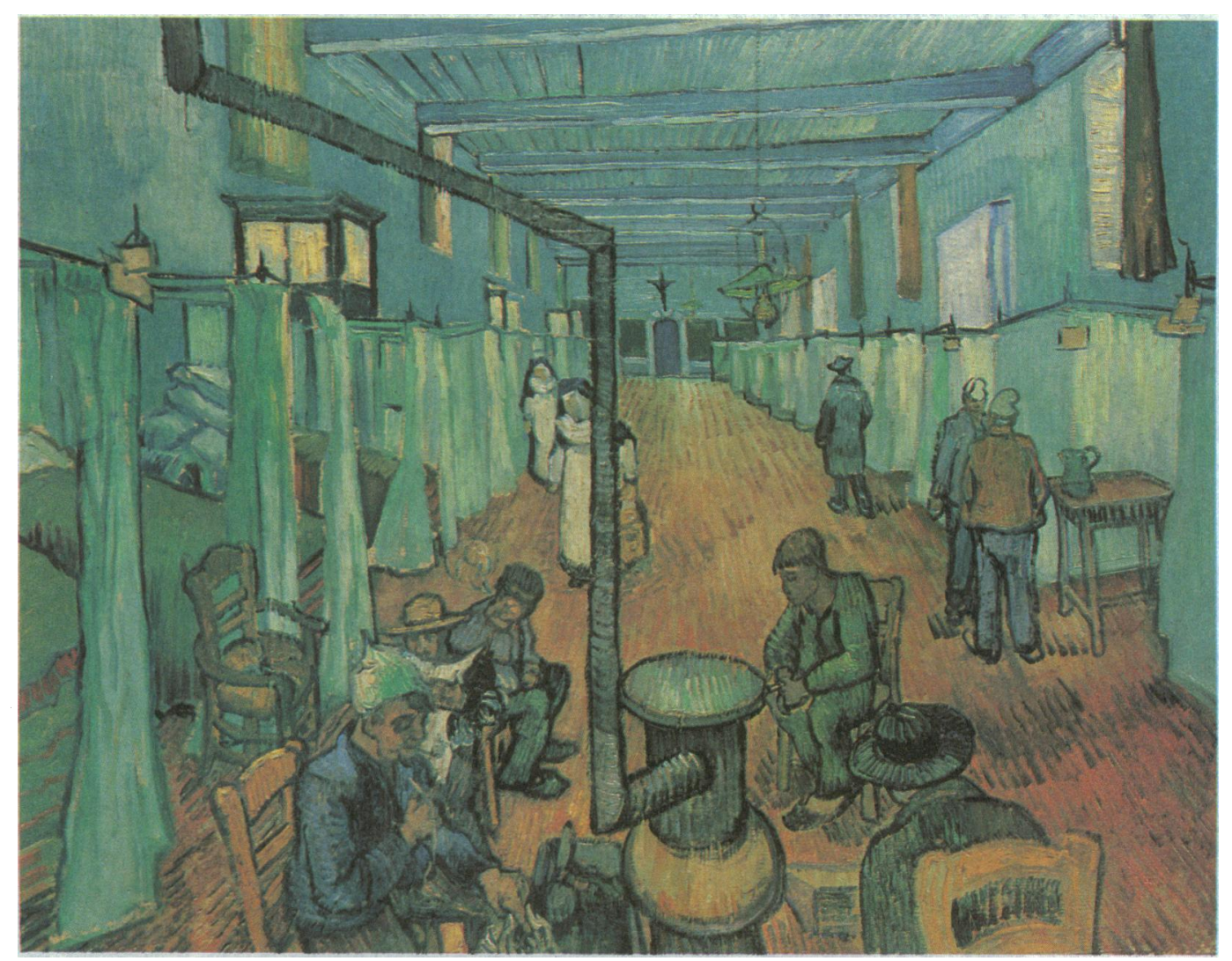


society or bank headquarters, he thought; and it was only after wandering round the perimeter for 20 minutes and coming across a group with placards protesting against the poll tax that he realised that this palace was the Department of Social Services. In the past our finest new buildings were cathedrals and churches. When you cry for help you need to identify its source easily.

\section{Criticisms and confidences} day.

Three letters typify the other 15 that arrived that

I am disgusted by your cruel comments . . . do you not think these parents have suffered enough, do you never think of them . . . its about time you and your sort did some useful work preventing death . . . you are evil and I hope your soul rots in hell.

I've never dared write this before but now feel I can. . . My husband's a solicitor and a good husband but he would never understand this and I never dared tell anyone. . . . When she was little I had this terrible urge to kill her, I wasn't mad, I wasn't ill and I've not needed psychiatric treatment. I loved her really but sometimes I just wanted to smother her. It stopped about the time she was 3 . She's a lovely girl now but I've never forgotten it and always felt guilty.

You may recognise the name because mother was quite famous and always appearing in the magazines and newspapers and on the radio. I am now 57 but I can't forget what she did to me, and for years afterwards I screamed and had hysterics every time I was taken to the bathroom. My aunt remembers how I used to shake all over for 5-10 minutes when she tried to bath me and that the neighbours complained about my screams. I know it was my mother, but why didn't my father do anything about it? He was so passive, getting on with his work. He was to blame too.

\section{Allegations}

"When I changed her nappy I noticed this bubbling and glistening."

"No it wasn't semen, it was as if she had been sexually excited."

Her barrister explained the reasons for believing that the 2 year old had been sexually abused during a Saturday visit to her father. It was a polished performance by the barrister because he had had a lot of practice. Allegations of sexual abuse had become the standard weapon in custodial disputes concerning children when marriages broke up. Even if the allegations foundered a father could be prevented from seeing his daughter for a couple of years as the legal proceedings meandered on.
"It was my uncle who did it, I was about 10 at the time but I never told anyone else about it, he did it with me sitting on his knee." She had killed one child and caused brain damage to another. She agreed with the workers from the five different agencies who were seeing her that her behaviour was really "a cry for help" because of the fact that she had been sexually abused as a child. Nowadays nearly all have been sexually abused as a child, and yet, until five years ago, hardly any of them made that claim. Is sexual abuse more common, more acceptable, or just convenient?

She was crying. "Don't worry," he said, "this medicine and ointment will soon get it better; she'll quickly be alright again."

"But I should have brought her so much earlier," she sobbed, "Its been going on two weeks . . . with the infection being there I didn't dare take her to my GP let alone to you. After that Cleveland business I thought you'd take her away from me."

"But you know she's not been sexually abused: you don't even have a man in the house, and she's not been left with a man. How could any of us suggest she could have been sexually abused?"

"I was frightened you would, and now I feel so awful-she's been crying for two weeks and I never helped."

It had been a round trip of nearly $800 \mathrm{~km}$ that he'd made one weekend because she'd telephoned-a call for help if not a cry for help. She wasn't there because that morning she'd taken an overdose and been admitted to hospital. Some weeks later he did see her. "I know what you've done, I understand it and I can help you," he said, "I know you really loved her." She could not remember exactly what she'd done or when she'd done it, but she accepted the forensic evidence that she must have done it. That was what she said.

Eight years later she came to see him. She seemed a different person; she had self respect, a new man, a new job, and also a new memory. She smiled at him, and it was a nice caring smile. "In a way you were so weak, sort of wet; I needed to be told that I was wrong and bad."

"What were you feeling when you did it?"

"It was a Friday morning, the back door was open, the milk bottles were on the doorstep, and the sun was shining on the bush in the yard. I was ironing her blouse and I knew I hated her. I really hated her." 